\title{
ENZYMATIC CONVERSION OF 7-HYDROXYGUANINE TO ITS NUCLEOSIDES
}

\author{
Mikio Kitahara, Kiyoto Ishil, Takeshi OKazaki, \\ TAKAYOSHI Hidaka and KiYoshi Watanabe \\ Biochemical Research Laboratories, Kanegafuchi Chemical Industry Co., Ltd., \\ Takasago, Hyogo, Japan
}

(Received for publication March 29, 1986)

\begin{abstract}
7-Hydroxyguanine, an antitumor purine-analog, reacted with ribose (or deoxyribose)-1phosphate in the presence of purine nucleoside phosphorylase. We prepared 7-hydroxyguanine riboside and deoxyriboside using purine nucleoside phosphorylase from bovine spleen. Each nucleoside exhibits antitumor activity against mouse leukemia L1210 cells. The therapeutic effect of 7-hydroxyguanine deoxyriboside is superior to those of 7-hydroxyguanine and 7-hydroxyguanine riboside.
\end{abstract}

In earlier publications we have described the isolation of 7-hydroxyguanine, an antitumor agent, from a strain of Streptomyces purpurascens ${ }^{1,2}$. In this study we have investigated the synthesis and antitumor activities of 7-hydroxyguanine nucleosides. This study have been influenced by the observation that, although 6-mercaptopurine is a useful purine-analog in cancer chemotherapy, 6-mercaptopurine riboside (thioinosine) inhibits growth of adenocarcinoma, over a wider non-lethal dosage range than 6-mercaptopurine ${ }^{3)}$.

Purine nucleoside phosphorylase (EC 2.4.2.1) which catalyzes the reaction:

$$
\text { purine }+ \text { pentose-1-phosphate } \rightleftharpoons \text { purine nucleoside }+ \text { orthophosphate }
$$

has been used for the enzymatic preparation of 7-hydroxyguanine nucleosides.

\section{Materials and Methods}

\section{Materials}

7-Hydroxyguanine was prepared as described previously ${ }^{1)} . \quad \alpha$-D-Ribose-1-phosphate barium salt and $\alpha$-D-2'-deoxyribose-1-phosphate barium salt were prepared according to the procedures described by Plesner and KLenow ${ }^{4)}$ and Friedkin ${ }^{5)}$. Purine nucleoside phosphorylase (PNPase) was purchased from Sigma. Chelating ion exchange resin, Chelex 100, was purchased from Bio-Rad Laboratories.

\section{HPLC Analysis}

The passage of the enzymatic reaction was monitored by HPLC with Nihonbunko $\mathrm{V}$ system and Partisil 10 SCX column $(4.6 \times 250 \mathrm{~mm})$ developed with a mobile phase of $10 \mathrm{~mm}$ $\mathrm{NH}_{4} \mathrm{H}_{2} \mathrm{PO}_{4}$ buffer ( $\left.\mathrm{pH} 3.0\right)$ at a flow rate of 1.0 $\mathrm{ml} /$ minute. 7-Hydroxyguanine riboside, 7-hydroxyguanine deoxyriboside and 7-hydroxyguanine were detected by UV absorption at $254 \mathrm{~nm}$ at 5.0 , 6.8 and 8.2 minutes of retention time, respectively.

Fig. 1. Structure of 7-hydroxyguanine nucleosides.

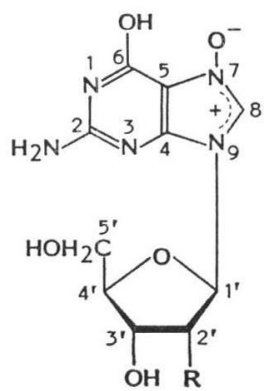

7-Hydroxyguanine riboside $\quad \mathrm{R}=\mathrm{OH}$ 7-Hydroxyguanine deoxyriboside $\mathrm{R}=\mathrm{H}$ 
Table 1. Physico-chemical properties of 7-hydroxyguanine nucleosides.

\begin{tabular}{|c|c|c|}
\hline & 1 & 2 \\
\hline Appearance & Colorless needle & Colorless needle \\
\hline $\mathrm{MP}\left({ }^{\circ} \mathrm{C}, \mathrm{dec}\right)$ & $138 \sim 139$ & $136 \sim 137$ \\
\hline$[\alpha]_{\mathrm{D}}^{20}\left(c 0.5, \mathrm{H}_{2} \mathrm{O}\right)$ & $-31.6^{\circ}$ & $-30.8^{\circ}$ \\
\hline FAB-MS $(m / z)$ & $300(\mathrm{M}+1)^{+}$ & $284(\mathrm{M}+1)^{+}$ \\
\hline Molecular formula & $\mathrm{C}_{10} \mathrm{H}_{13} \mathrm{~N}_{5} \mathrm{O}_{6}$ & $\mathrm{C}_{10} \mathrm{H}_{13} \mathrm{~N}_{5} \mathrm{O}_{5} \cdot \mathrm{H}_{2} \mathrm{O}$ \\
\hline Anal Found: & C $39.88, \mathrm{H} 4.31, \mathrm{~N} 23.45$. & C 40.03, H 5.12, N 23.40 . \\
\hline Calcd: & C $40.14, \mathrm{H} 4.32, \mathrm{~N} 23.40$. & C 39.87, H 5.02, N 23.25 . \\
\hline $\mathrm{UV} \lambda_{\max }^{\mathrm{H}_{2} \mathrm{O}} \quad \mathrm{nm}(\varepsilon)$ & $236(18,200), 268(9,400)$ & $234(19,100), 267(9,800), 282(\mathrm{sh})$ \\
\hline$\lambda_{\max }^{0.1 \mathrm{M} H \mathrm{Cl} 1} \mathrm{~nm}(\varepsilon)$ & $260(10,600), 280(\mathrm{sh})$ & $254(10,900), 272(\mathrm{sh})$ \\
\hline$\lambda_{\max }^{0.1 \mathrm{M} \mathrm{NaOH}} \mathrm{nm}(\varepsilon)$ & $234(17,000), 276(8,800)$ & $234(20,400), 278(10,300)$ \\
\hline $\operatorname{IR}\left(\mathrm{cm}^{-1}, \mathrm{KBr}\right)$ & $\begin{array}{l}3350,1700,1635,1614,1582 \\
1560,1460,1240,1130,870\end{array}$ & $\begin{array}{l}3330,1710,1680,1633,1590 \\
1520,1455,1060,925,778\end{array}$ \\
\hline${ }^{1} \mathrm{H}$ NMR (ppm, $\mathrm{D}_{2} \mathrm{O}$ ) & $\begin{array}{l}5.85(\mathrm{~d}, 1 \mathrm{H}), 4.59(\mathrm{t}, 1 \mathrm{H}), \\
4.34(\mathrm{t}, 1 \mathrm{H}), 4.18(\mathrm{q}, 1 \mathrm{H}), \\
3.82(\mathrm{~m}, 2 \mathrm{H})\end{array}$ & $\begin{array}{l}6.27(\mathrm{t}, 1 \mathrm{H}), 4.54(\mathrm{~m}, 1 \mathrm{H}) \\
4.06(\mathrm{~m}, 1 \mathrm{H}), 3.73(\mathrm{~m}, 2 \mathrm{H}) \\
2.4 \sim 2.7(\mathrm{~m}, 2 \mathrm{H})\end{array}$ \\
\hline $\mathrm{Rf}$ on $\mathrm{TLC}^{\mathrm{a}}$ & 0.05 & 0.16 \\
\hline
\end{tabular}

a Silica gel (Merck 5715) BuOH - EtOH - $\mathrm{CHCl}_{3}-17 \% \mathrm{NH}_{4} \mathrm{OH}, 4: 5: 2: 2$.

Preparation of 7-Hydroxyguanine Riboside (1)

7-Hydroxyguanine $(1.33 \mathrm{~g})$ and ribose-1-phosphate barium salt $(7.31 \mathrm{~g})$ were dissolved in $800 \mathrm{ml}$ of $50 \mathrm{~mm}$ sodium citrate buffer $\left(\mathrm{pH} \mathrm{6.5)}\right.$ at $40^{\circ} \mathrm{C}$. The reaction was started by the addition of 400 units of PNPase. After incubation for 2 hours at $40^{\circ} \mathrm{C}, 61 \%$ of 7 -hydroxyguanine was converted to 1 . The reaction mixture was cooled with ice and centrifuged at 3,000 rpm for 10 minutes. The supernatant $(2,073 \mu \mathrm{g} / \mathrm{ml}, 805 \mathrm{ml})$ was applied to a column of Chelex $100\left(\mathrm{Ni}^{2+}, 350 \mathrm{ml}\right)$ and eluted with $0.3 \mathrm{M}$ $\mathrm{NH}_{4} \mathrm{OH}$. The active eluate $(1,832 \mu \mathrm{g} / \mathrm{ml}, 800 \mathrm{ml})$ was passed through a column of Amberlite IRC 50 $\left(\mathrm{NH}_{4}{ }^{+}, 250 \mathrm{ml}\right)$, to remove $\mathrm{Ni}^{2+}$. The passage was concentrated to $15 \mathrm{ml}$ and then $15 \mathrm{ml}$ of ethanol was added. After 16 hours in the refrigerator, 1 formed as white precipitate was collected and dried in vacuo $(1.44 \mathrm{~g})$.

The white powder $(1.44 \mathrm{~g})$ was dissolved in $20 \mathrm{ml}$ of hot water and placed in the refrigerator, yielding colorless needles of $\mathbf{1}(1.15 \mathrm{~g})$.

Preparation of 7-Hydroxyguanine Deoxyriboside (2)

7-Hydroxyguanine $(760 \mathrm{mg})$ and deoxyribose-1-phosphate barium salt $(2.5 \mathrm{~g})$ were dissolved in $1,150 \mathrm{ml}$ of $50 \mathrm{~mm}$ sodium citrate buffer $(\mathrm{pH} 6.5)$. The reaction was started by the addition of 500 units of PNPase. After incubation for 2 hours at $40^{\circ} \mathrm{C}, 84 \%$ of 7 -hydroxyguanine was converted to 2. The reaction mixture was cooled with ice and centrifuged at $3,000 \mathrm{rpm}$ for 10 minutes. The supernatant $(941 \mu \mathrm{g} / \mathrm{ml}, 1,150 \mathrm{ml})$ was applied to a column of Chelex $100\left(\mathrm{Ni}^{2+}, 400 \mathrm{ml}\right)$ and eluted with $0.2 \mathrm{M} \mathrm{NH}_{4} \mathrm{OH}$. The active eluate $(796 \mu \mathrm{g} / \mathrm{ml}, 1,600 \mathrm{ml})$ was passed through a column of Amberlite IRC $50\left(\mathrm{NH}_{4}{ }^{+}, 300 \mathrm{ml}\right)$. The passage was evaporated in vacuo and dried, yielding white powder $(2.3 \mathrm{~g})$. The white powder $(2.3 \mathrm{~g})$ was dissolved in $20 \mathrm{ml}$ of hot water and placed in the refrigerator. After 16 hours in the refrigerator 2 formed as colorless needles $(868 \mathrm{mg})$.

\section{Results and Discussion}

\section{Physico-chemical Properties}

7-Hydroxyguanine riboside (1) and 7-hydroxyguanine deoxyriboside (2) are soluble in water, very slightly soluble in dimethyl sulfoxide, and almost insoluble in methanol, benzene, chloroform and hexane. $\mathbf{1}$ and $\mathbf{2}$ gave positive reactions with Folin-Ciocalteu reagent and orcinol-ferric chloride-sulfuric acid but showed a negative test with ninhydrin.

Physico-chemical properties of $\mathbf{1}$ and $\mathbf{2}$ are summarized in Table 1. Proton magnetic resonance 
Table 2. ${ }^{13} \mathrm{C}$ NMR chemical shifts in 7-hydroxyguanine nucleosides*.

\begin{tabular}{crr|ccc}
\hline Position & \multicolumn{1}{c}{$\mathbf{1}$} & $\mathbf{2}$ & Position & $\mathbf{1}$ & $\mathbf{2}$ \\
\hline 2 & 151.70 & 151.56 & $1^{\prime}$ & 85.49 & 87.32 \\
4 & 151.14 & 151.53 & $2^{\prime}$ & 70.78 & 35.65 \\
5 & 98.57 & 98.50 & $3^{\prime}$ & 69.75 & 71.38 \\
6 & 153.16 & 153.34 & $4^{\prime}$ & 84.91 & 81.13 \\
8 & 147.32 & 147.10 & $5^{\prime}$ & 62.30 & 62.40 \\
\hline
\end{tabular}

* Spectra were recorded on a Varian XL-300 in DMSO- $d_{6}$.

study indicates that $\mathbf{1}$ and $\mathbf{2}$ have $8-\mathrm{CH}$ signals at 8.42 and 8.32 ppm respectively in dimethyl sulfoxide solution, while in aqueous solution the $8-\mathrm{CH}$ signals of $\mathbf{1}$ and $\mathbf{2}$ are not observed. The results in aqueous solution would due to the hydrogen exchange reaction of $8-\mathrm{CH}$ with solvent as well known in the case of 7-methylguanosine ${ }^{6)}$. In dimethyl sulfoxide solution the $2-\mathrm{NH}_{2}$ signals of 1 and 2 are observed at 6.78 and $6.88 \mathrm{ppm}$, but the 1-NH signals are not observed. So the hydrogen atoms may be located on $6-\mathrm{O}$. The ${ }^{13} \mathrm{C}$ NMR chemical shifts observed for $\mathbf{1}$ and $\mathbf{2}$ are given in Table 2.
Table 3. In vivo antitumor activity of 7-hydroxyguanine nucleosides against leukemia L1210.

\begin{tabular}{lccc}
\hline & \multicolumn{4}{c}{$\mathrm{T} / \mathrm{C}(\%)^{\mathrm{b}}$} \\
\cline { 2 - 4 } Dose $^{\mathrm{a}}$ & $\mathbf{1}$ & $\mathbf{2}$ & $\begin{array}{c}\text { 7-Hydroxy- } \\
\text { guanine }^{15}\end{array}$ \\
\hline 0.5 & 108 & 107 & 124 \\
1 & 118 & 116 & 135 \\
2 & 135 & 112 & 145 \\
4 & 148 & 146 & 151 \\
8 & 157 & 144 & 119 \\
16 & 152 & 161 & Toxic \\
32 & 99 & 120 & \\
\hline a & mg/kg/day, day 1 5 (ip). 6 mice in each group. \\
b & T/C (\%) means survival period of treated/mean \\
\multicolumn{3}{l}{ survival period of controls. }
\end{tabular}

\section{Antitumor Activity}

7-Hydroxyguanine nucleosides exhibited a prolongation effect in the survival period of mice inoculated with the mouse leukemia L1210 cells. Lymphoid leukemia L1210, $10^{5}$ cells per mouse were inoculated intraperitoneally into female mice $\left(\mathrm{BDF}_{1}\right.$ strain). 7-Hydroxyguanine nucleosides were administered to mice intraperitoneally 24 hours after tumor inoculation. The treatments were given once daily for 5 days. The results are shown in Table 3 . The therapeutic effect of the riboside (1) is equal to that of 7-hydroxyguanine and the deoxyriboside (2) is slightly superior. The acute toxicity of $\mathbf{1}$ and $\mathbf{2}$ were determined in male mice (ICR strain) by single intraperitoneal administration, the LD $\mathrm{D}_{50}$ 's of 1 and 2 were in the range $148 \sim 248 \mathrm{mg} / \mathrm{kg}$ and $150 \sim 198 \mathrm{mg} / \mathrm{kg}$, respectively.

\section{References}

1) Kitahara, M.; K. Ishit, Y. Kumada, T. Shiraishi, T. Furuta, T. Miwa, H. Kawaharada \& K. WataNABE: 7-Hydroxyguanine, a novel antimetabolite from a strain of Streptomyces purpurascens. I. Taxonomy of producing organism, fermentation, isolation and biological activity. J. Antibiotics 38: 972 976, 1985

2) Kitahara, M.; K. Ishit, H. Kawaharada, K. Watanabe, T. Suga, T. Hirata \& S. Nakamura: 7Hydroxyguanine a novel antimetabolite from a strain of Streptomyces purpurascens. II. Physico-chemical properties and structure determination. J. Antibiotics 38: 977 980, 1985

3) Skipper, H. E.; J. A. Montgomery, J. R. Thomson \& F. M. Schabel, Jr.: Structure-activity relationships and cross-resistance observed on evaluation of a series of purine analogs against experimental neoplasms. Cancer Res. 19: 425 459, 1959

4) Plesner, P. E. \& H. Klenow: Preparation of ribose-1-phosphate. In Methods in Enzymology. Vol. 3. Eds., S. P. Colowik \& N. O. Kaplan, pp. 181 182, Academic Press Inc., London, 1957

5) Friedkin, M.: Desoxyribose-1-phosphate. II. The isolation of crystallin desoxyribose-1-phosphate. J. Biol. Chem. 184: 449 459, 1950

6) Nakanishi, M.; M. Tsuboi \& I. Nakagawa: On the chemical structure and some labile hydrogens of 7-methylguanosine. Bull. Chem. Soc. Jpn. 49: 2011 2012, 1976 